\title{
The 2017 Trump Administration travel ban and international graduate applications at two Texas public universities
}

\author{
Dana Van De Walker and John R. Slate
}

Sam Houston State University/ United States

\begin{abstract}
The purpose of this study was to determine the extent to which the Trump administration ban on individuals from 7 Muslim-majority countries (i.e., Executive Order 13769), influenced prospective international graduate applicants to two Texas institutions. Inferential statistical procedures revealed the presence of a statistically significant, sharp decline in international graduate applicants, particularly from Muslim-majority countries. From Fall 2016 to Fall 2018, international graduate applicants from non-Muslim-majority countries declined $18.36 \%$. Over this same time period, applicants from Muslim-majority countries declined $33.37 \%$. Most notably, applicants from the 7 countries targeted in the travel ban declined 53.93\%. Concerns clearly exist regarding the effects of this travel ban on international student mobility. Implications of these findings and recommendations for future research are discussed.
\end{abstract}

Keywords: international students, Muslim students, government policy, Trump administration, travel ban

Raya Bidshahri, an Iranian student at Boston University, quipped "We are treated like we're terrorists, as if we want to cause trouble when above all we just want to make the United States a better place -- contributing whether it's through research, studying, or entrepreneurship" (Lewin, 2017, para. 7). Bidshahri, who was beginning her final semester of college in January 2017, was one of the many international students and scholars directly affected by the Trump administration ban on individuals from seven Muslim-majority countries, or Executive Order 13769 (2017). As new political administrations take power, changes in official government immigration policy follow, oftentimes affecting international student mobility and the 
lives of current international students (Rose-Redwood \& Rose-Redwood, 2017). When a specific set of the population is targeted in immigration policies, such as individuals from Muslim-majority countries, the consequences for current and prospective international students, United States (U.S.) institutions, and the greater U.S. economy are pronounced.

Raya Bidshahri, an Iranian student at Boston University, quipped "We are treated like we're terrorists, as if we want to cause trouble when above all we just want to make the United States a better place -- contributing whether it's through research, studying, or entrepreneurship" (Lewin, 2017, para. 7). Bidshahri, who was beginning her final semester of college in January 2017, was one of the many international students and scholars directly affected by the Trump administration ban on individuals from seven Muslim-majority countries, or Executive Order 13769 (2017). As new political administrations take power, changes in official government immigration policy follow, oftentimes affecting international student mobility and the lives of current international students (Rose-Redwood \& Rose-Redwood, 2017). When a specific set of the population is targeted in immigration policies, such as individuals from Muslim-majority countries, the consequences for current and prospective international students, United States (U.S.) institutions, and the greater U.S. economy are pronounced.

\section{LITERATURE REVIEW}

Universities in the U.S. are increasingly turning to international student enrollment as a way to enhance their campus diversity efforts and promote study abroad, crosscultural understanding, and global learning opportunities among their domestic students (Prinster, 2016). International student mobility, in turn, is dependent on a variety of push/pull (Mazzarol \& Soutar, 2002) factors that influence student decision-making behaviors as they pertain to educational advancement. Mazzarol and Soutar described push factors as those factors that originate "within the source country and initiate a student's decision to undertake international study" (p. 82) and pull factors as those factors that originate "within a host country to make that country relatively attractive to international students" (p. 82). Although push/pull factors vary among students, some push factors include family expectations, restrictive career and study opportunities, and discrimination in students' home countries. Some pull factors include the perceived quality of academics, ability to improve English skills, and immigration opportunities in the host country (Macrander, 2017).

In spite of this increased effort on the part of U.S. institutions to recruit foreign students, international student mobility is being gradually redirected to other higher education markets, such as Canada (Mueller, 2009). Mueller (2009) focused on the decline in perceived immigration opportunities for Muslim students and scholars following the September 11, 2001 terrorist attacks in New York City. Using data from the U.S. Citizenship and Immigration Service and Citizenship and Immigration Canada, he identified this marked change in Muslim student mobility. Specifically, he found that enrollment in U.S. universities by students from predominately Muslim countries declined by more than $60 \%$ between 2001 and 2002 . These compelling findings open opportunities for other scholars to study the impact of notable political 
events on Muslim student mobility. Other researchers have focused on the complexities of the relationships between Muslim students' experiences and campus environments. In their 2010 article on the experiences of a Black Muslim woman on a U.S. college campus, McGuire et al. (2010) explored the concept of Muslim otherness and the perceptions of white students on Muslim students of color. They further pointed out the psychosocial implications of the "continued significance of post-9/11 Islamophobia in the lives of Muslim college students" (p. 325). Using longitudinal survey data from Muslim students and their Jewish and Christian peers, Cole and Ahmadi (2010) investigated how the experiences of Muslim students differed from their non-Muslim peers. They concluded that, although Muslim students were highly engaged in interactional diversity, they were less satisfied with their university experience and bore a substantial psychological load. Such psychological weight, much of which remains as an effect of the September 11, 2001 terrorist attacks and corresponding rise of Islamophobia in the U.S., has been compounded for many Muslim students with the rise of the Trump administration.

Researchers from a variety of backgrounds and disciplines are turning to Trump administration events, and their impact on immigrant communities and students of color, as a source of research interest. For example, Pyle, Linvell, and Gennett (2017) used a mixed methods study to qualitatively assess the responses of 300 institutions to the Trump administration ban on individuals from Muslim-majority countries. Using axial coding, they assigned a score to those institutions that were proactive in their response, those institutions that were reactive, and those institutions that had no official response. These data were then quantitatively correlated with the 2016 Electoral College vote for the state in which the institution belongs. Rose-Redwood and Rose-Redwood (2017) further investigated the effect of the Trump administration ban, examining its effect on international student mobility. In their article, the researchers highlighted the timeline of the ban, including its three versions, and called upon professionals in the field of education to study correlational relationships between changes in government immigration policy and the effects on international student mobility, retention, and experience. The literature on the topic of Muslim international student mobility offers a very clear message: Political events and instability can have an evident impact on international student mobility and, as a result, Muslim international students may feel less welcome in the U.S.

\section{Theoretical Framework}

Integrated Threat Theory (ITT) has been employed in this study as a guiding theoretical framework. The theory was established by Stephan and Stephan in 2000 as a psychological theory explaining xenophobic phenomena. The researchers, having conducted extensive prior research on in-group/out-group relations, sought to create a theory to better characterize racist and xenophobic reactions by members of an in-group towards members of an out-group. ITT contains four critical components: (a) realistic threats, (b) symbolic threats, (c) intergroup anxiety, and (d) negative stereotypes. Using their model of ITT, Stephan and Stephan (2000) described realistic threats as those threats, or perceived threats, by the out-group that compromise the "very existence of the in-group" (p. 25). Examples of realistic threats might include 
warfare or conflict, or loss of resources, such as job or educational opportunities. Symbolic threats, however, include perceived differences in beliefs, customs, or values toward religion, family, and language between the in-group and out-group. Intergroup anxiety, as characterized by the researchers, refers to lukewarm racism or fear of being labeled a racist. Lastly, negative stereotypes are those threats that contribute to the continued negative public perception of out-group members.

Numerous researchers have tested the validity of ITT since its establishment in 2000. Stephan and Stephan (2000) led with an original test of the theory on immigrants in the U.S.. The researchers explored in-group impressions of Mexican, Cuban, and Asian immigrants in New Mexico, Florida, and Hawaii. They discovered that in these communities, realistic threats, symbolic threats, and negative stereotypes all had a statistically significant impact as predictors of prejudice towards immigrants. Then, Corenblum and Stephan (2001) analyzed intergroup tension between white Canadians and First Nations people. The researchers designed and utilized a negative stereotype index for the purpose of analyzing this tension. Similar to the original test, these researchers observed that perceived threats were directly correlated with negative attitudes towards out-group members, in this case, the First Nations people.

Outside the U.S. and Canada, researchers have used ITT to test xenophobia and prejudice in their own communities. Velasco González, Verkuyten, Weesie, and Poppe (2008) adopted ITT in their study on the attitudes of Dutch teenagers toward Muslim minority groups. Using Berry and Kalin's (1995) scale of multicultural ideologies, the researchers focused primarily on symbolic threats and negative stereotypes, concluding that these components of ITT increased prejudice amongst the Dutch teens (Velasco González et al., 2008). Similarly, Tausch, Hewstone, and Roy (2009) used ITT to test levels of prejudice between Hindus and Muslims in India. Specifically, they used a series of measures adapted from Islam and Hewstone (1993) and Stephan and Stephan (1985). In this study, Hindus, or the in-group members, were determined to have symbolic threats as a predictor of prejudice, whereas Muslims, or the out-group members, were determined to have realistic threats as a predictor of prejudice. Interestingly, intergroup anxiety was a predictor of prejudice for both groups (Tausch et al., 2009).

Just as many researchers have utilized ITT in studying xenophobia towards immigrant groups, some researchers have employed ITT as a theoretical framework for studies involving international students. Harrison and Peacock (2010) tested ITT on attitudes of British domestic students toward international students at two universities in England. Through a series of focus groups, they documented that negative stereotypes of international students contributed to their feelings of "otherness" (p. 19). Similarly, perceived symbolic threats led to domestic students viewing international students as culturally separate, leading to an exclusion of international students from their friend groups. Charles-Toussaint and Crowson (2010) tested ITT among American and international students at a university in the southwest U.S., focusing on realistic and symbolic threats. The researchers used a Likert scale based on several previous measures, including Danso, Sedlovskaya, and Suanda's (2007) immigration attitudes measure. They noted that American students, similar to their British peers, experienced perceived threats correlated with increased prejudice toward international students. 
The ITT was selected as a theoretical framework for this study because it highlights the racist and xenophobic attitudes that international students can experience when choosing to study in the U.S.. Though finances, personal goals, and curriculum are all items students must consider when contemplating an overseas education, they must also weigh the national political climate and overall campus atmosphere - they must prioritize their safety. Given the 2016 U.S. presidential election and the subsequent Trump administration ban on individuals from seven Muslim-majority countries, international students are faced with an increasingly complex web of educational decisions. Viewing international graduate student application rates at Texas universities through the lens of ITT allows readers to contemplate the psychological hurdles that international students must navigate. Certainly, the Trump administration ban had immediate negative implications, like visa denials and refusals of entry, for students from the affected countries, but it also unleashed a wave of Islamophobia and xenophobia felt by many international students. Explored in this investigation were the effects of the ban, not only on students from Iran, Iraq, Libya, Somalia, Sudan, Syria, and Yemen, but also on the rest of the Muslim student world and international students as a whole.

\section{PURPOSE}

The purpose of this study was to determine the extent to which the Trump administration ban on individuals from seven Muslim-majority countries (Executive Order 13769), enacted in January 2017, affected the number of international students who applied to graduate programs at Texas universities. For the purpose of this study, all initiated applications, including those applications completed and those applications left incomplete, were included. Focused on in this investigation was the application rate (the dependent variable) over the course of two unique time periods (the independent variable): (a) Fall 2016, approximately four months before the ban was enacted, to Fall 2017, approximately 8 months after the ban was enacted; and (b) Fall 2017 to Fall 2018, more than one and a half years after the ban was enacted.

\section{Significance}

The term diversity has been a buzzword in the world of higher education for longer than many university students have existed. For most institutions, the aim to foster campus diversity has prompted them to expand study abroad programs, promote more international partnerships, and, of course, recruit international students. In fact, during the 2016-2017 academic year, more than one million international students studied in the U.S., comprising more than five percent of the total U.S. college and university enrollment (Institute of International Education, 2017). Immigration events, such as the closing of an embassy or the enacting of new government policy, can directly affect both international students and the institutions that seek to host them (Rose-Redwood \& Rose-Redwood, 2017). One such new government policy, the Trump administration ban on individuals from seven Muslimmajority countries, or Executive Order 13769, enacted January 27, 2017, has been the 
topic of heated debate among career politicians and international higher education administrators alike.

The Trump administration ban prohibited entry to the U.S. for passport-holders from Iraq, Iran, Libya, Somalia, Sudan, Syria, and Yemen for an initial 90-day period (Redden, 2018a). Immediately after the ban was announced, it was challenged on legality grounds and was enjoined by federal courts. The ban was then superseded by a second and third version, both of which were challenged by federal courts. The second iteration of the ban excluded Iraqi nationals, along with permanent residents and those with valid U.S. visas, including student visas. The final iteration of the ban became more country-specific and included limitations on mobility for North Korean and Venezuela passport-holders (Redden, 2018a). At the time of writing, the U.S. Supreme Court upheld the Trump administration's third ban in a 5-4 vote, citing that President Trump was within his realm of authority to enact security regulations in the interest of promoting homeland security (Redden, 2018b). The timeliness of this study is predicated on the recency of both the ban and the Supreme Court decision ruling alongside the Trump administration.

\section{Research Questions}

The following research questions were addressed in this study: (a) To what extent did the number of international applications from students from non-Muslim-majority countries to graduate programs at two major Texas universities change?; (b) To what extent did the number of international applications from students from 47 identified Muslim-majority countries to graduate programs at two major Texas universities change?; and (c) To what extent did the number of international applications from students from Iran, Iraq, Libya, Somalia, Sudan, Syria, and Yemen to graduate programs at two major Texas universities change? Each research question is addressed separately for the two time periods: Fall 2016 to Fall 2017 and Fall 2017 to Fall 2018.

\section{RESEARCH DESIGN}

A correlational, longitudinal, causal comparative design was employed in this quantitative, nonexperimental research study (Gay \& Airasian, 2000; Menard, 2008). This design was nonexperimental because only archival data was utilized. By using data from several time periods, longitudinal designs can also highlight changes in the variables over time (Menard, 2008). This study was longitudinal because the dependent variable (international graduate student application rates at two Texas public universities) for two distinct time periods-Fall 2016 to Fall 2017 and Fall 2017 to Fall 2018 - was examined. Correlational designs have been identified as designs which seek to determine a relationship between two or more variables and utilize data collected from two or more time periods (Gay \& Airasian, 2000; Menard, 2008). Although cause and effect connections cannot be established between variables, correlational designs can "use these relationships to make predictions" (Gay \& Airasian, 2000, p. 321). This study was correlational because the relationship between established time periods (i.e., before, shortly after, and after the Trump 
administration ban on individuals from Muslim-majority countries) and the application rates for international graduate students at two Texas public universities were explored. Such a design also permits the ability to make predictions about the possible effects of changes in U.S. immigration policy on international student mobility.

\section{Sampling Method}

Purposive sampling was utilized in this study. Suitable institutions were first identified for the study, then were narrowed down to two distinct time periods and to one specific target population-international graduate students. Many higher education administrators have questioned how the Trump presidency has affected international graduate students in particular, given that international graduate student mobility to the U.S. had been growing steadily in the years leading up to the 2016 election (Bhattacharyya, 2017). The two institutions selected for this study were selected because they rank in the top five host institutions for international students in the State of Texas (IIE, 2017). Included in that ranking were two other research institutions, both of whom declined to participate in the study because they lacked the ability to retrieve the required data, and one community college, which was excluded because it is a 2-year institution and therefore does not offer graduate programs. The sample for this study consisted of 52,656 applicants. All international graduate student application rate data from the two participating institutions were used and separated into the three categories identified in the research questions.

\section{Data Source and Procedures}

Data were acquired for this study through the submission of open records requests to the offices of institutional effectiveness at each institution. Both institutions confirmed access to the needed data, which included a full redaction of students' personal information. Identified in the data set were individual students' countries of origin, which, for the purpose of this study, was defined as the country for which they bore a passport. Permanent residents, along with refugees, asylum seekers, undocumented students, and those undergoing adjustment of status were excluded as they do not possess an F1 student visa and therefore are not considered international students. Specifically requested was that the applicant lists for Fall 2016, Fall 2017, and Fall 2018 be accurate as of the census date (in the case of both institutions, the 12th class day) to control for late or unprocessed applications, adding reliability and validity to the study. After the data set was secured, it was converted into the format suitable for the Statistical Package for the Social Sciences (SPSS), which allowed the researcher to analyze the data.

\section{RESULTS}

Prior to calculating inferential statistical procedures, the underlying assumptions of the statistical technique, the Pearson chi-square procedure, were checked. Pearson chi-square analyses were conducted because the independent variable was categorical in nature (i.e., all international students, students from the 47 Muslim-majority 
countries, and students from the seven countries affected by the travel ban) in each time period (i.e., Fall 2016 to Fall 2017, Fall 2017 to Fall 2018). Chi-square analyses are the most appropriate choice in examining two categorical variables (Slate \& Rojas-LeBouef, 2011). Because both variables in each research question were categorical variables, Pearson chi-square analyses were suitable. Due to the large sample size, the available cell sample size was greater than five for each research question, thus confirming the decision to conduct chi-square analyses.

For the first two research questions regarding the change in application rates for all international students and students from the 47 Muslim-majority countries, the result was statistically significant, $\chi^{2}(1, N=52,656)=28.71, p<.001$. The effect size of this result, Cramer's V, was very small, .02 (Cohen, 1988). As detailed in Table 1, international graduate applicants from non-Muslim-majority countries declined by $18.36 \%$ from Fall 2016 to Fall 2018. In contrast, readers should note that international graduate applicants from 47 Muslim-majority countries declined by $33.37 \%$ from Fall 2016 to Fall 2018. Readers are directed to Figure 1 for a graphic representation of this decline.

Table 1: Frequencies and Percentages of International Graduate Applicants from Muslim-majority Countries (Category A) and all Other Countries (Category B) by Semester

\begin{tabular}{lccc}
\hline & Fall 2016 & Fall 2017 & Fall 2018 \\
Country of Origin & $n$ and \% of Total & $n$ and \% of Total & $n$ and \% of Total \\
\hline Category A & $(n=1,804) 39.60 \%$ & $(n=1,544) 33.90 \%$ & $(n=1,202) 26.40 \%$ \\
Category B & $(n=17,745) 36.90 \%$ & $(n=15,874) 33.00 \%$ & $(n=14,487) 30.10 \%$
\end{tabular}

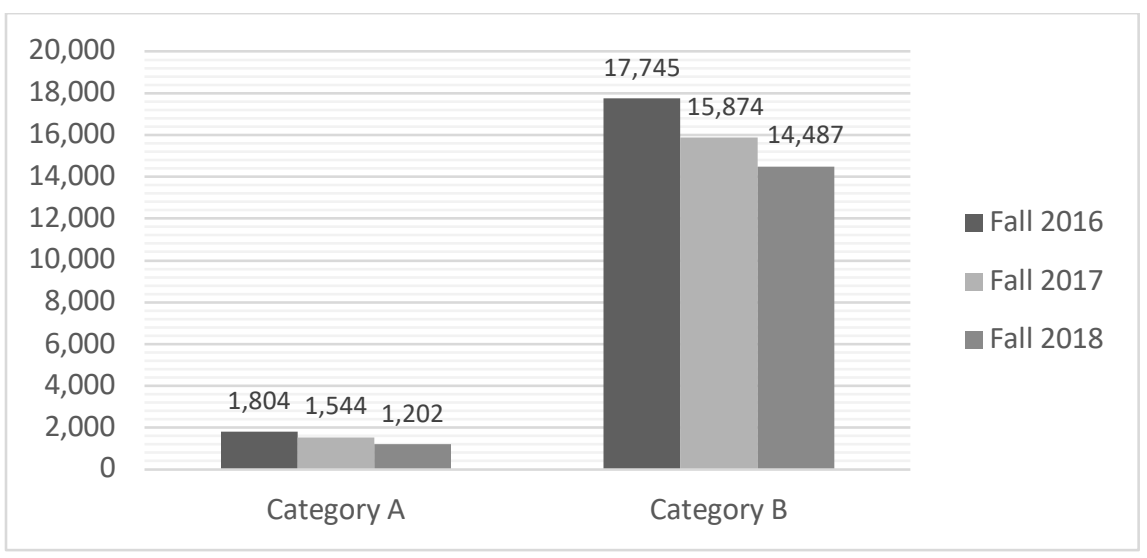

Figure 1: Graphic representation of decline in international graduate applicants from Muslim-majority countries (Category A) and all other countries (Category B) by semester. 
With respect to the third research question on the change in application rates for international graduate applicants from the seven countries affected by the travel ban, a statistically significant difference was revealed, $\chi^{2}(1, N=1463)=68.54, p<.001$. The Cramer's V effect size for this result was very small, .03 (Cohen, 1988). As revealed in Table 2, international graduate applicants from the seven countries affected by the travel ban declined by 53.93\% from Fall 2016 to Fall 2018. This decline is represented in Figure 2.

Table 2: Frequencies and Percentages of International Graduate Applicants from Countries Affected by the Travel Ban (Category A), all Other Muslimmajority Countries (Category B), and all Other Countries (Category C) by Semester

\begin{tabular}{lccc}
\hline & Fall 2016 & Fall 2017 & Fall 2018 \\
Country of Origin & $n$ and \% of Total & $n$ and \% of Total & $n$ and \% of Total \\
\hline Category A & $(n=649) 44.40 \%$ & $(n=515) 35.20 \%$ & $(n=299) 20.40 \%$ \\
Category B & $(n=1,155) 37.40 \%$ & $(n=1,029) 33.30 \%$ & $(n=903) 29.30 \%$ \\
Category C & $(n=17,745) 36.90 \%$ & $(n=15,874) 33.00 \%$ & $(n=14,487) 30.10 \%$ \\
\hline
\end{tabular}

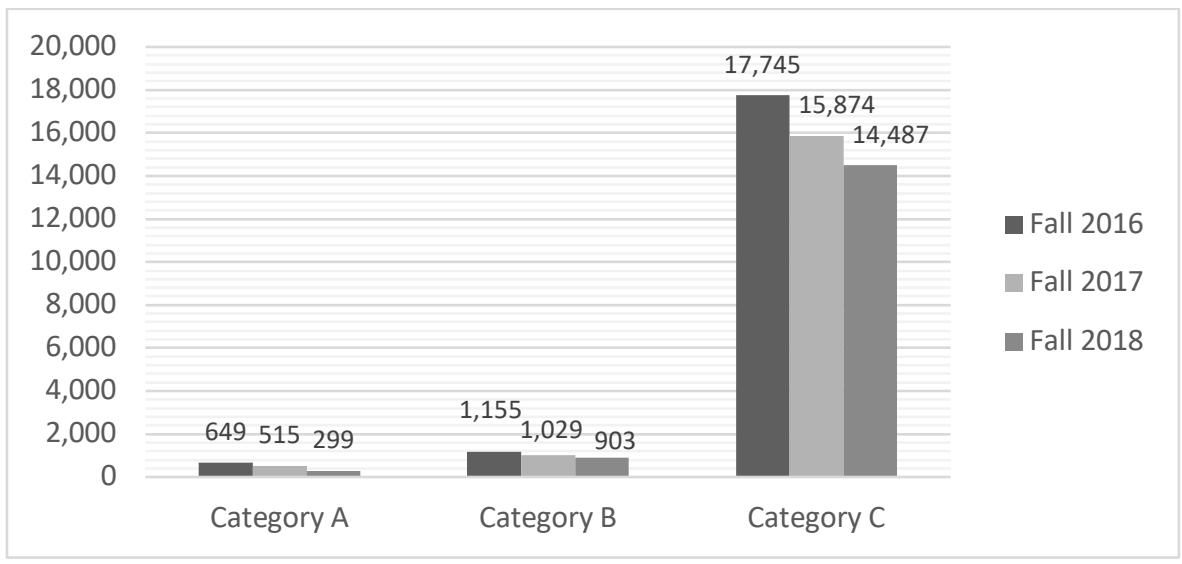

Figure 2. Graphic representation of decline in international graduate applicants from countries affected by the travel ban (Category A), all other Muslim-majority countries (Category B), and all other countries (Category C) by semester.

\section{DISCUSSION}

Revealed in this study were statistically significant declines, not only in the number of international graduate applicants from all countries to two Texas universities, but also in the number of applicants from Muslim-majority countries - most notably was the amount of decline in applications from countries affected by the Trump administration travel ban. Although the effect size for each statistically significant 
analysis was very small, the dataset used contained application information for more than 52,000 international graduate applicants, and highlighted in the results of this study is a very concerning trend in international student mobility. Fewer and fewer international students are choosing to study at Texas institutions. Indeed, regarding the institutions sampled for this study, 3,258 fewer prospective international students applied for a graduate program in Fall 2018 compared to Fall 2016. This decline of $18.36 \%$ represented a serious problem for university administrators who view international students as sources of academic talent, diversity, and tuition funds.

The most concerning results in this study were the decline of students from Muslim majority countries and students from the countries affected by the travel ban. Regarding the two Texas institutions sampled in this study, 602 fewer prospective international students from Muslim-majority countries (all) applied in Fall 2018 compared to Fall 2016. These students from Egypt, Indonesia, and beyond, which represent a $33.37 \%$ decline, are a significant loss to the state of Texas. Most shockingly, 350 fewer students from the seven countries affected by the Trump travel ban applied for graduate programs in Fall 2018 compared to Fall 2016. This number of students may appear to be small compared to the grand number of international students in the U.S., but it represents a troubling decline of $53.93 \%$. Texas institutions ought to be concerned by these alarming statistics.

\section{Recommendations for Future Research}

This study is the only known empirical study (by those who conducted this study) in which the effects of the Trump administration travel ban on international student mobility have been investigated. As such, some limitations exist, presenting opportunities for expanded versions of this study along with opportunities for related research. Two of the primary limitations of this study include the small sample size and the focus only on graduate applications. To expand upon this important line of inquiry, researchers may posit the following questions: (a) In what ways has the Trump travel ban affected international graduate applications to universities in other states, particularly states that went "blue" (e.g., in which the majority of voters represented changed from Republican to Democrat) in the 2016 presidential election?; (b) In what ways has the Trump travel ban affected international graduate applications to universities throughout the U.S.?; (c) In what ways has the Trump travel ban affected international applications at all levels (including for undergraduate, English language, and technical programs)?; and (d) Have international student application rates to Canada, Australia, and other alternative education destinations increased to coincide with the Trump travel ban?

Some researchers may also opt to view this marked decline in international student mobility with a wider lens. Wider-ranging research questions may include the following: (a) How has the changing political environment surrounding immigration in the U.S. affected the ways in which Muslim international students perceive their educational, career, and immigration goals?; (b) What fiscal damage can result from sharp declines in international student mobility, both at the institutions and in the communities that host international students?; and (c) How 
have Trump administration immigration policies and changes to the U.S. political environment affected mobility of international faculty and staff? A meaningful addition to each of these questions is, What are the long-term effects of changes in immigration policy on international education in the U.S.?

\section{CONCLUSION}

For many higher education administrators and researchers, the future of international education in the U.S. is bleak and woefully dependent on the immigration policy whims of the current presidency. Similar to many of her international student peers, Raya Bidshahri, the Iranian Boston University student introduced at the start of this paper, relocated to Canada (Lapowsky, 2017.). She had hoped to move to Silicon Valley following her graduation to put her degree in Neuroscience to use in the field of technology (Thadani \& Fracassa, 2017). However, following the announcement of the Trump travel ban she stated, "This shatters my dreams of being in the valley" (para. 6). At the time of writing, Bidshahri, who now calls Toronto home, is the founder of an educational technology startup, a motivational speaker, and a social media entrepreneur.

When international students make decisions about their educational, career, and immigration goals, they must consider a variety of factors, not least of which is the political and economic climate of their potential destinations (Bista \& Dagley, 2014). Rohan Roberts, Bidshahri's colleague in Canada, noted "The political climate in the U.S. is volatile and uncertain - and unstable - particularly for immigrants" (Mascarenhas, 2017, para. 30). University administrators should not only take note of changes in immigration policy but should also recognize how such immigration policy changes can affect their students, their campuses, and their communities as a whole.

\section{REFERENCES}

Berry, J. W., \& Kalin, R. (1995). Multicultural and ethnic attitudes in Canada. An overview of the 1991 national survey. Canadian Journal of Behavioural Sciences, 27, 301-320.

Bhattacharyya, A. (2017). International Students in the Age of Trump. Diverse: Issues in Higher Education, 34(6), 20-21.

Bista, K., \& Dagley, A. (2014). Higher education preparation and decision-making trends among international students. College and University, 90(3), 2-11.

Charles-Toussaint, G. C., \& Crowson, H. M. (2010). Prejudice against international students: The role of threat perceptions and authoritarian dispositions in U.S. students. The Journal of Psychology, 144(5), 413-428.

Cohen, J. (1988). Statistical power analysis for the behavioral sciences (2nd ed.). Hillsdale, NJ: Lawrence Erlbaum.

Cole, D., \& Ahmadi, S. (2010). Reconsidering campus diversity: An examination of Muslim students' experiences. The Journal of Higher Education, 81(2), 121139. doi:10.1080/00221546.2010.11779045 
Corenblum, B., \& Stephan, W. G. (2001). White fears and native apprehensions: An integrated threat theory approach to intergroup attitudes. Canadian Journal of Behavioral Science, 33(4), 251-268.

Cubillo, J., Sánchez, J., \& Cerviño, J. (2004). International students' decision-making process. International Journal of Educational Management, 20(2), 101-115. doi:10.1108/09513540610646091

Danso, H. A., Sedlovskaya, A., \& Suanda, S. H. (2007). Perceptions of immigrants: Modifying the attitudes of individuals higher in social dominance orientation. Personality and Social Psychology Bulletin, 33, 1113-1123.

Gay, L. R., \& Airasian, P. W. (2000). Educational research: Competencies for analysis and application (6th ed.). Upper Saddle River, NJ: Merrill/Prentice Hall.

Harrison, N., \& Peacock, N. (2010). Cultural distance, mindfulness and passive xenophobia: Using Integrated Threat Theory to explore home higher education students perspectives on internationalisation at home. British Educational Research Journal, 36, 877-902. doi:10.1080/014119209031191047

Institute of International Education [IIE]. (2017). International students enrollment trends, 1948/49-2016/2017. Open Doors Report on International Educational Exchange. Retrieved from http://www.iie.org/opendoors

Islam, M. R., \& Hewstone, M. (1993). Dimensions of contact as predictors of intergroup anxiety, perceived out-group variability, and out-group attitude: An integrative model. Personality and Social Psychology Bulletin, 19, 700-710.

Lapowsky, I. (2017, July). Trump's policies are sending precious startup jobs to Canada. WIRED. Retrieved from https://www.wired.com/story/pausinginternational-entrepreneur-rule-sends-jobs-to-canada/

Lewin, L. (2017, January). These are the faces of Trump's ban. CNN. Retrieved from https:/www.cnn.com/interactive/2017/01/politics/immigration-ban-stories/

Macrander, A. (2017). An international solution to a national crisis: Trends in student mobility to the United States post 2008. International Journal of Educational Research, 82, 1-20. doi:10.1016/j.ijer.2016.12.003

Mascarenhas, N. (2017, February). Why this student entrepreneur is uprooting her American dream. Bostinno. Retrieved from https://www.americaninno.com/boston/student-entrepreneur-edtech-startupgoes-to-canada-after-trump-immigration-ban/

Mazzarol, T., \& Soutar, G. N. (2002). "Push-pull" factors influencing international student destination choice. International Journal of Educational Management, 16(2), 82-90. doi:10.1108/09513540210418403

McGuire, K. M., Casanova, S., \& Davis, C. H. F., III. (2016). “I'm a Black female who happens to be Muslim": Multiple marginalities of an immigrant Black Muslim woman on a predominantly white campus. The Journal of Negro Education, 85(3), 316-329.

Menard, S. (2008). Handbook of longitudinal research: Design, measurement, and analysis. New York, NY: Academic Press.

Mueller, R. E. (2009). Does the Statue of Liberty still face out? The diversion of foreign students from the United States to Canada in the post 9/11 period. The Canadian Journal of Higher Education, 39(1), 15-43. 
Pew Research Center (2011). The future of the global Muslim population. Washington, D.C. Retrieved June 21, 2018 from http://assets.pewresearch.org/wpcontent/uploads/sites/11/2011/01/FutureGlobalMuslimPopulation-WebPDFFeb10.pdf

Prinster, R. (2016, June 28). International students provide colleges a mutually beneficial relationship. INSIGHT Into Diversity. Retrieved from http://www.insightintodiversity.com

Pyle, A. S., Linvill, D. L., Gennett, S. P. (2017). From silence to condemnation: Institutional responses to "travel ban" Executive Order 13769. Public Relations Review, 44, 214-233. doi: 10.1016/j.pubrev.2017.11.002

Redden, E. (2018a). A year of travel bans. Retrieved June 21, 2018, from https://www.insidehighered.com/news/2018/02/01/year-later-trumpadministrations-travel-restrictions-opposed-many-higher-ed-are

Redden, E. (2018b). Supreme Court upholds Trump's travel ban. Retrieved June 27, 2018, from https://www.insidehighered.com/news/2018/06/27/supreme-courtupholds-trumps-travel-ban-5-4-ruling

Rose-Redwood, C., \& Rose-Redwood, R. (2017). Rethinking the politics of the international student experience in the age of Trump. Journal of International Students, 7(3), I-IX. doi:10.5281/zenodo.569939

Slate, J. R., \& Rojas-LeBouef, A. (2011). Calculating basic statistical procedures in SPSS: A self-help and practical guide to preparing theses, dissertations, and manuscripts. Ypsilanti, MI: NCPEA Press.

Stephan, W. G., \& Stephan, C. W. (1985). Intergroup anxiety. Journal of Social Issues, 41, 157-175.

Stephan, W. G., \& Stephan, C. W. (2000). An integrated theory of prejudice. In S. Oskamp (Ed.), Reducing prejudice and discrimination (pp. 23-45). New York, NY: Psychology Press.

Tausch, N., Hewstone, M., \& Roy, R. (2009). The relationships between contact, status, and prejudice: An Integrated Threat Theory analysis of Hindu-Muslim relations in India. Journal of Community and Applied Social Psychology, 19, 8394.

Thadani, T., \& Fracassa, D. (2017, February). Trump order dashes hopes of wouldbe entrepreneurs. San Francisco Chronicle. Retrieved from https://www.sfchronicle.com/business/article/Trump-order-dashes-hopes-ofwould-be-entrepreneurs-10901727.php

Thomas, K. J. A., \& Inkpen, C. (2017). Foreign student emigration to the United States: Pathways of entry, demographic antecedents, and origin-country contexts. International Migration Review, 51(3), 789-820. doi:10.1111/imre. 12265

Velasco González, K., Verkuyten, M., Weesie, J., \& Poppe, E. (2008). Prejudice towards Muslims in The Netherlands: Testing integrated threat theory. British Journal of Social Psychology, 47(4), 667-685. doi:10.1348/014466608X284443 
Dana Van De Walker, is a Doctoral Candidate in the Department of Institutional Leadership at Sam Houston State University, where she works in the Office of International Programs. She has nearly 15 years of experience in international education.Email: djv013@shsu.edu

John R. Slate, PhD, is a Full Professor Department of Institutional Leadership at Sam Houston State University. There he teaches doctoral courses in basic and advanced statistics. To date, he has chaired well over 100 doctoral students to completion. Email:jrs051@shsu.edu 